\title{
Cooperation Amidst Calamity: The Impact of the Covid-19 Pandemic Between China and Indonesia Resulting in Shared Needs
}

\author{
Hermini Susiatiningsih \\ Department of International Relations \\ Universitas Diponegoro \\ Semarang, Indonesia \\ herminisusi@lecturer.undip.ac.id
}

Safriska Desna Putri

Department of International Relations

Universitas Diponegoro

Semarang, Indonesia

safriskadp@gmail.com

\author{
Marten Hanura \\ Department of International Relations \\ Universitas Diponegoro \\ Semarang, Indonesia \\ marten.h@live.undip.ac.id
}

\author{
Khairunnisa Andini Damayanti \\ Department of International Relations \\ Universitas Diponegoro \\ Semarang, Indonesia \\ khairunnisaandini@students.undip.ac.i
}

\author{
Tri Cahyo Utomo \\ Department of International Relations \\ Universitas Diponegoro \\ Semarang, Indonesia \\ tricahyoutomo@gmail.com
}

\begin{abstract}
Nowadays, the world is experiencing the Covid-19 pandemic. Following the increasing COVID-19 cases and the implementation of social distancing and lockdown policies across countries, new problems have emerged from the international community. The problems arising are copious, ranging from economic problems due to intensifying unemployment rates, increasing people's distrust of the state government, as well as social problems. In June 2020, the World Bank through Global Economic Prospects predicted a decline of 5.2 percent of total world GDP in 2020 as a result of the COVID-19 pandemic. Also, the World Bank estimates that the economies of developed countries will decline by 7 percent. The decline in the economies of developed countries will eventually affect the economies of developing countries, which are predicted to experience a decline of 2.5 percent. In addition to the worsening international conditions due to Covid-19, China and Indonesia are among the countries dealing with the same issue. The purpose of this article is to understand the impact of the COVID-19 Pandemic for both countries by using qualitative research methods, finding that the impact of the covid-19 pandemic between the two countries creates shared needs to resolve this issue by carrying out bilateral cooperation that brings mutual benefits.
\end{abstract}

Keywords: the impact of covid-19, Indonesia, China, the basis of bilateral cooperation

\section{INTRODUCTION}

Currently, the world is in the Covid-19 pandemic. The disease that attacks the human respiratory tract first appeared in Wuhan City, China, on December 1, 2019 [1]. At the beginning of its emergence, this disease was called 'Wuhan pneumonia' or 'Wuhan pneumonia disease' because the symptoms experienced by sufferers were similar to those of pneumonia. The World Health Organization (WHO) introduced the name 'COVID-19' or Coronavirus Disease 2019 through the WHO Situation Report on 11 February 2020. At that time, the spread of the COVID-19 had only occurred in mainland China and several Asian and Middle Eastern countries [2]. Then, on 11 March 2020, WHO Director-General, Dr. Tedros Adhanom, stated that COVID-19 is officially classified as a pandemic. It was decided following the spread of the disease which had reached 118,000 cases in more than 110 regions around the world [3].

With the continued increase in Covid-19 cases and the implementation of social distancing and lockdown policies in several countries, new problems have emerged from the international community. The problems arising are various, ranging from economic problems as a result of intensifying unemployment rates, increasing people's distrust of the state government, as well as social problems such as racism and xenophobia cases. In June 2020, the World Bank through Global Economic Prospects predicted a decline of 5.2 percent of total world GDP in 2020 due to the Covid-19 pandemic. Furthermore, the World Bank also estimates that the economy of developed countries will decline by 7 percent. The decline in the economies of developed countries will eventually affect the economies of developing countries, which are predicted to experience a decline of 2.5 percent [4]. The International Monetary Fund (IMF) also predicts that the implementation of a stricter lockdown policy will 
have an impact on reducing consumption, investment, and production levels, and simultaneously will lead to an increase in the number of unemployment. The IMF highlights the importance of the government not only focusing on controlling the spread of the Covid-19 pandemic in their home countries but also considering the increase of unemployment and poverty rates [5].

In addition to the worsening international conditions due to Covid-19, China and Indonesia are among the countries dealing with the same thing. The Chinese Center for Disease Control and Prevention (CDC) reveals that as many as 500,000 people in Wuhan have been infected with this virus [6]. Meanwhile, the development of Covid-19 in Indonesia is still not showing improvement. As of December 2020, there were 743,198 confirmed cases of COVID19 in Indonesia and it continues to grow [7]. This virus has impacted Indonesia in various aspects, such as economic and employment problems. As a result, many companies went bankrupt and downsized their employees, unemployment increased, and employment decreased [8].

Several previous studies have been done related to this research topic. The research conducted by Rudolf (2021) with the title China's Health Diplomacy during Covid 19: The Belt and Road Initiative (BRI) in Action probed that the COVID-19 pandemic became a momentum for China to prove itself as a country [9]. Large companies had international responsibility with assistance provided by China in the form of sending medical personnel, masks supplies, respirator, and test kits. Another study by Chow-Bing (2020) entitled COVID-19, Belt, and Road Initiative and Health Silk Road: Implication for Southeast Asia reported that the COVID-19 pandemic hurt the economic sector, which led to the Belt and Road Initiative (BRI) project) [10]. China is unlikely to continue. Therefore, China is now focusing its attention on the Health Silk Road (HSR) which emphasizes health programs for BRI countries.

Meanwhile, Gauttam et al (2020) entitled COVID19 and Chinese Global Health Diplomacy: Geopolitical Opportunity for China's Hegemony? that studied China's foreign policy, especially global health diplomacy, which encouraged China to provide medical assistance to many countries, including the United States and the European Union [11]. This action then allowed new avenues for China's global health diplomacy and improved its image in other regions, such as Africa and Europe as well as Asia.

From some of the research above, we understand that there are discrepancies that there is no research that discusses the overall impact of the Covid-19 pandemic on each country where it is the foundation for cooperation to overcome the covid pandemic collectively. Thus, this study proposes this novelty.

\section{DISCUSSION}

\section{A. Social, Economic, and Political Impacts in China Due to Covid-19}

The Covid-19 pandemic that has hit countries around the world has forced restrictions on human interaction through lockdowns or self-isolation. This certainly brings various repercussions on the country's state, such as in terms of social, economic, and political. As the epicenter and starting point for the emergence of the pandemic, China is one of the many countries that has been severely affected by the Covid-19 pandemic. The impacts are as follows:

\section{1) Social Impact}

Since the discovery of the first Covid-19 cluster at the Huanan Fish Market at the end of January 2020, the Chinese government had set a policy to use masks for all Wuhan residents. However, the government still allowed citizens to travel and use public facilities while wearing masks [6]. The new total lockdown was implemented in Wuhan on January 23, 2020, after several Covid-19 cases emerged outside China, such as in Thailand, Japan, South Korea, and the United States. This policy was also followed by banning residential entering complexes if not registered as permanent residents, closing restaurants, and mandatory selfisolation for residents who were traveling domestically and internationally [12].

The emergence of the Covid-19 pandemic brought several social impacts for China. One of the social impacts experienced by China is in the education milieu. China was the first country to shut down public places, including schools, universities, and other educational institutions. This policy forced many students in China to start distance learning activities. It was recorded that around 200 million children in China started distance learning in February 2020. To preempt this circumstance, the Chinese Ministry of Education launched the "national online learning platform", which is a distance learning system supported by 7,000 internet servers that can be accessed by 50 million school students, comprising elementary and high school at the same time [13].

Another social impact that prompts the most global concern is the increasing number of Sinophobia. Sinophobia is a term used to describe anti-Chinese sentiments, both culture, Chinese society, and their descendants [14]. Sinophobia has increased dramatically following the announcement of Covid-19 as a pandemic by the WHO. The forms of these actions vary, ranging from discrimination and violence targeting Chinese descents in other countries, as well as postings profanities on social media that insult China and its citizens. In February 2020, there were at least 50 reports of violence and discrimination against citizens of Asian descent in Italy [15].

Soaring cases of Sinophobia made the Office of the High Commissioner of United Nations Human Rights 
(OHCHR) urge the governments of world countries to implement National Action Plans against Racial Discrimination (NAPARD) [16].

\section{2) Economic Impact}

In addition to the social impact, the Covid-19 pandemic has also influenced the economy in China and other countries globally. Recorded in February 2020, the Caixin/Markit stock index experienced a sharp decline to 26.5 from the index of 51.8 in January. This figure is the lowest figure yet for 40 years. This was partly due to the lockdown and self-isolation policies implemented by the Chinese government, which affected the economy [17]. In addition, the Covid-19 pandemic has also had a detrimental impact on the number of workers in China. According to a report from the International Labor Organization (ILO), at the end of January 2020, 90 percent of catering businesses in China had closed [18]. The results of a survey conducted by the Chinese Employers' Confederation also showed that of the total of 299 companies that were respondents, more than half suffered losses, and more than 60 percent were forced to lay off some of their employees or downsize recruitment quota for new employees [18]

The lockdown and self-isolation policies implemented by the Chinese government to reduce the spread of Covid-19 also affected China's gross domestic product or GDP, in which China's GDP figure was contracted by 10 percent in the first quarter of 2020. It was exacerbated by consumption figures that were only able to contribute as much as -4.4 percent, investment -1.5 percent, and net profit from trade as much as -1 percent [19]. Furthermore, there were 8.74 million students who graduated and needed jobs in 2020. This number did not include 300,000 foreign students and 2019 graduate students who were still unemployed [20].

\section{3) Political Impact}

China is one of the important actors in global politics. Unfortunately, the Covid-19 pandemic has labeled China wrong before other countries. It is because the first case of Covid-19 came from China. As explained in subchapter 2.3.1., one of the impacts is the increasing number of Sinophobia or discrimination against China, culture, and Chinese society. This Sinophobic action was also done by world leaders, such as the 45th President of the United States, Donald Trump, who referred to Covid-19 as the "Chinese Virus" in his speech at the White House in March 2020 as well as his statements on social media Twitter [21]. On another occasion, Trump also referred to Covid-19 as "Kung Flu" [22]. Furthermore, the former United States Secretary of State, Mike Pompeo, also referred to Covid-19 as "Wuhan Virus" in a virtual meeting of G-7 countries [23].

At the same time, the world government's dissatisfaction with China is allegedly due to the "wolf warrior" diplomatic method applied by China. "Wolf warrior" diplomacy is an offensive stance taken by Chinese diplomats to defend China's national interests. This attitude often spreads to the confrontational phase. This method has been implemented since 2010 but has become a worldwide concern following the Covid-19 pandemic [24]. By applying the "wolf warrior" diplomacy method, China is deemed to have missed the opportunity to contribute and commit to multilateralism.

One example of "wolf warrior" diplomacy was when China participated in the Coronavirus Global Response Summit which was held on May 4, 2020. When other countries sent their leaders and prime ministers as state representatives, China sent one of its ambassadors, Zhang Ming, who is the country's representative with the lowest position among representatives of other countries [25]. Furthermore, during the meeting, the Chinese government only pledged US\$50 million in aid funds to the WHO to deal with the global spread of Covid-19. This amount was the opposite of the amount promised by Germany, which was 625 million US dollars, and France 595 million US dollars [26].

\section{B. Social, Economic and Political Impacts in Indonesia Due to Covid-19}

In the course of a year, Indonesia has undergone many ups and downs in the number of confirmed cases. After various efforts and policies issued by the government, the number of Covid-19 cases has gradually decreased. In the latest data as of March 14, 2021, it was recorded that the addition of positive cases was 4,714, active cases were 137,912 cases and recovered cases were 1,243.11 cases, and mortality reached 38,426 cases [27]. One form of development to prevent the spread of this virus is the inclusion of a vaccine in Indonesia, which was first injected into President Joko Widodo at the Presidential Palace on January 13, 2021 [28]. Despite all the efforts and policies implemented, the spread of this virus certainly has a significant impact on several aspects, encompassing social, economic, and political impacts.

\section{1) Social Impact}

One of the impacts of Covid-19 is changes in social conditions. Several social impacts occur in Indonesian society, such as new normal life and panic buying. The people's negligence in perceiving rapidly changing conditions such as many dismissals and layoffs will allow for social crises such as criminal acts in the form of theft, burglary, and robbery [29]. Thus, in the social aspect, the impact of Covid-19 on the community is a change in a new habit and the emergence of social phenomena, one of which is panic buying,

The Covid-19 outbreak that hit Indonesia forced Indonesia to adapt to new conditions known as the new normal. New normal is a habitual organization of community behavior that adapts to current conditions such as the implementation of clean living, wearing 
masks, and "PSBB" [30]. The new normal life indirectly changes all forms of people's behavior in social life. So in other words, the new normal is carrying out activities as usual yet implementing health protocols such as washing hands regularly, implementing PSBB, and wearing masks [31]. The adaptation of this new habit was implemented on May 20, 2020, in the Decree of the Minister of Health $[32,33]$. This application then generates a dilemma for society between economic interests and fears of contracting the Covid-19 virus. The implementation of this new habit then changes people's lifestyle in socializing, in which people are still required to do activity optimally but do not ignore the protocols that must be applied to break the chain of the spread of this virus [34].

\section{2) Economic Impact}

The emergence of the Covid-19 virus certainly has a significant impact on the Indonesian economy. Vice President Ma'ruf Amin (Kompas, 2021) stated that the vaccine program is needed to resolve the pandemic as a way to restore global economic conditions [35]. According to Statistics Indonesia, the emergence of this pandemic disrupted the inflation system in Indonesia [36]. Minister of Finance, Sri Mulyani also revealed that Covid-19 had hit the economy more or less. The implementation of the PSBB launched by the government has affected the production process, distribution, and operational activities, which eventually increases unemployment and poverty rates [37]. In employment, the job market also changes recruitment, during the Covid-19 period, companies prefer workers who are more capable in technology because of current conditions that demand this skill [8]. Broadly speaking, some of the economic impacts that occurred were a decrease in economic growth and an increase in the unemployment rate.

National economic growth in 2020 has decreased. In the first quarter (January-March) economic growth was at 2.97 percent, but in the second quarter where the implementation of the PSBB was intensively implemented, economic growth decreased once again by 5.32 percent [37]. The Vice President of the Republic of Indonesia, Ma'ruf Amin (Kompas, 2020) affirmed that due to the Covid-19 virus, production activities, public consumption, and investment were diminishing [35]. The decline in economic growth is in line with the employment sector. Termination of Employment (PHK) is rife in the pandemic era [38]. This resulted in an increase in the unemployment rate from 2.56 million people to 9.77 million people, even the number of formal workers fell but informal workers increased [37]. According to the Ministry of Manpower as of April 7, 2020, the impact of Covid-19 has resulted in 39,977 formal companies laying off their employees [8]. During the Covid-19 outbreak, the number of unemployed became 9.7 million and the open unemployment rate reached 7.07 percent [39]. This is partly due to considering that around 57 percent of the
Indonesian population only possesses education level of junior high school and below and has limited abilities, which is in contrast to the needs of companies that are undergoing labor transformation and require workers in the field of technology.

\section{3) Political Impact}

In addition to the changing economic and social sectors due to Covid-19, this virus has transformed Indonesia's political stability. Covid-19 has resulted in a political crisis related to the level of public trust in all forms of government action [40]. Secretary-General of the Indonesian Ulema Council (MUI), Anwar Abbas (CNN, 2020) expressed that Covid-19 could seriously disrupt the state of stability [41]. However, Indonesia's domestic political conditions are still relatively safe, the democratic process, regional elections, and forms of freedom of expression are still being applied and not disrupted [42]. Meanwhile, regarding relations between countries, due to Covid-19, Indonesia intensively needs to increase cooperation between countries to resolve this pandemic. Minister of Finance, Sri Mulyani (Tempo, 2020) said that in establishing political relations, Indonesia continues to collaborate and establish communication with the Asian Development Bank (ADB) to resolve these problems, both in the health and economic fields [43]

The declining economic growth rate has also become the basis for Indonesia in the past year to continue to establish political relations, especially with ASEAN, both in research development, information exchange, financial support, economic diplomacy, as well as technical assistance such as mutual support in the fields of tourism, investment, and trade [44].

\section{CONCLUSION}

The Covid-19 pandemic has brought many upheavals and transformations for all sectors in Indonesia and China. Economic, social, and even political changes are important aspects for both countries. Thus, both countries need various actions and policies to be able to overcome this situation. One of the policies required is to establish a form of cooperation between the two countries. Indonesia-China Bilateral Cooperation during this pandemic focuses on the vaccine supply process. As widely known, the Indonesian government administered the Sinovac vaccine made in China for the vaccination program for the Indonesian people. Indonesia and China also cooperate in ensuring equal access to vaccines.

\section{ACKNOWLEDGMENT}

We would like to thank all those who have helped to complete this article, especially the Faculty of Social and Political Sciences, Universitas Diponegoro, which has sponsored this research, and also our students who have assisted in this research, namely Aulianisa Rahma Dyah, Sapen Sartika Unyi Putri, Nurul Husna, Nabilla Rahma Sardi, Endah Tarwiyani and Ratu Fadilah Audzitni Rao. 


\section{REFERENCES}

[1] C. Huang, Y. Wang, X. Li, L. Ren, J. Zhao, Y. Hu, \& B. Cao Clinical features of patients infected with 2019 novel coronavirus in Wuhan, China. The lancet, 395(10223), 2020. 497-506.

[2] TIME. (2020, March 11). World Heath Organization Declares COVID-19 a 'Pandemic'. Here's What That Means [online]. Retrieved from https://time.com/5791661/who-coronaviruspandemic-declaration (Accessed February 11, 2021).

[3] WHO. Novel Coronavirus (2019-nCov) Situation Report-22, Jenewa: WHO. 2020.

[4] World Bank. Global Economic Prospects, June 2020, New York City: World Bank. 2020

[5] IMF. World Economic Outlook, New York City: IMF. 2020.

[6] CNN. Face masks are made mandatory in Wuhan. 2020. [online]

Retrieved from https://edition.cnn.com/asia/live-news/wuhancoronavirus-china-intl-

hnk/h b6ff0d4bd2e53b2ee9e5ca768e231811

[Accessed April 8, 2021].

[7] Kompas. (2020, December 31). Covid-19 [online]. Retrieved from https://www.kompas.com/covid-19_Accessed February 10, 2021).

[8] Kompas. (2020, August 11). Pandemi Covid-19 Apa Saja Dampak pada Sektor Ketenagakerjaan Indonesia [online]. Retrieved

from https://www.kompas.com/tren/read/2020/08/11/102500165/pa ndemi-covid-19-apa-saja-dampak-pada-sektorketenagakerjaan-indonesia-?page=all_(Accessed April 11, 2021).

[9] M. Rudolf. China's Health Diplomacy during Covid 19 : The Belt and Road Initiative (BRI) in Action. German Institute for International and Security Affairs, Januari 2021: 1-8 (doi:10.18449/2021C09).

[10] N. Chow-Bing. (October 2020). COVID-19, Belt and Road Initiative and Health Silk Road : Implication for Southeast Asia. Jakarta : Friedrich-Ebert-Stiftung Indonesia Office. 2020. [online]. Retrieved from https://asia.fes.de/news/healthsilk-road-pub [Accessed March 16, 2021].

[11] P., Gauttam, B. Singh, and J. Kaur. COVID-19 and Chinese Global Health Diplomacy: Geopolitical Opportunity for China's Hegemony?. Millennial Asia, 11(3). 2020. :318-340 (doi:10.1177/0976399620959771).

[12] A. Livermore, and D. Shira. The Social and Economic Impact of COVID-19 on China and its Recovery Potential. 2020.

[13] The Washington Post. In China, 200 millikon kids have gone back to school. 2020. [online]. Retrieved from https://www.washingtonpost.com/world/asia_pacific/inchina-200-million-kids-have-gone-back-to-schoolonline/2020/02/17/e5cc6f10-5131-11ea-80ce37a8d4266c09_story.html (Accessed April 9, 2021).

[14] The American Heritage Dictionary, n.d. Sinophobia. [online]. Retrieved from https://ahdictionary.com/word/search.html?q=Sinophobic (Accessed April 8, 2021).

[15] HRW. Covid-19 Fueling Anti-Asian Racism and Xenophobia Worldwide. 2020. [online]. Retrieved from https://www.hrw.org/news/2020/05/12/covid-19-fueling-antiasian-racism-and-xenophobia-worldwide (Accessed April 8, 2021).

[16] OHCHR. National Action Plans against Racial Discrimination, Geneva: OHCHR. 2013.

[17] South China Morning Post. Coronavirus: China's service sector drops to all-time low in latest blow to economy amid Covid-19 outbreak. 2020. [online]. Retrieved from https://www.scmp.com/economy/china- economy/article/3064907/coronavirus-chinas-services-sectordrops-all-time-low-latest (Accessed April 9, 2021).

[18] ILO. China - Rapid assessment of the impact of COVID-19 on employment, Geneva: ILO. 2020.

[19] Al-Haschimi, Alexander, A. Apostolou, and M. Ricci. China's path to normalisation in the aftermath of the COVID-19 pandemic. Economic Bulletin Articles 6. 2020.

[20] Global Times. GT investigation: Is China's job market facing risk of social instability. 2020. [online]. Retrieved from https://www.globaltimes.cn/content/1186821.shtml (Accessed April 10, 2021).

[21] The Atlantic. 2020 Time Capsule \#5: The 'Chinese Virus'. $2020 . \quad$ [online]. Retrieved from https://www.theatlantic.com/notes/2020/03/2020-timecapsule-5-the-chinese-virus/608260/?page $=1 \&$ oldest $=$ true (Accessed April 10, 2021)

[22] BBC News, President Trump calls coronavirus 'kung flu'. $2020 . \quad$ [online]. Retrieved from https://www.bbc.com/news/av/world-us-canada-53173436 [Accessed April 10, 2021].

[23] Politico. Pompeo, G-7 foreign ministers spar over 'Wuhan virus'. $2020 . \quad$ [online]. Retrieved from https://www.politico.com/news/2020/03/25/mike-pompeo-g7coronavirus-149425 (Accessed April 10, 2021).

[24] The Diplomat. Interpreting China's "Wolf Warrior Diplomacy". 2020. [online]. Retrieved from https://thediplomat.com/2020/05/interpreting-chinas-wolfwarrior-diplomacy/ (Accessed April 10, 2021).

[25] EU Coronavirus Global Response. Coronavirus Global Response Programme. 2020. [online]. Retrieved from https://global-response.europa.eu/programme_en [Accessed April 10, 2021)

[26] EU Coronavirus Global Response. Coronavirus Global Response Pledge Funds raised. 2020. [online]. Retrieved from https://global-response.europa.eu/pledge_en (Accessed April 10, 2021).

[27] Covid. Analisis Data Covid-19 Indonesia. 2021. [online]. Retrieved from https://covid19.go.id/p/berita/analisis-datacovid-19-indonesia-update-14-maret-2021__Accessed April 10, 2021).

[28] Kompas. (2021, January 13). Jokowi Disuntik Vaksin Pertama [online]. $\quad$ Retrieved from https://www.kompas.com/tren/read/2021/01/13/134500065/jo kowi-disuntik-vaksin-pertama-ini-cara-kerja-vaksin-sinovaccegah-covid-19? page=all (Accessed April 10, 2021).

[29] CNN. (2020, March 22). Alasan Psikologi di Balik Panic Buying [online]. Retrieved from https://www.cnnindonesia.com/gaya-hidup/20200322161747284-485813/alasan-psikologi-di-balik-panic-buying (Accessed April 10, 2021).

[30] Tirto. (2020, May 29). New Normal Indonesia Tatanan Baru Beradaptasi dengan Covid-19. [online]. Retrieved from https://tirto.id/arti-new-normal-indonesia-tatanan-baruberadaptasi-dengan-covid-19-fDB3 (Accessed April 10, 2021).

[31] Kementerian Keuangan Republik Indonesia. New Normal di Tengah Pandemi Covid-19. 2020. [online]. Retrieved from https://www.djkn.kemenkeu.go.id/kpknl-sidempuan/bacaartikel/13169/New-Normal-di-Tengah-Pandemi-Covid19.html (Accessed April 8, 2021)

[32] Kementerian Kesehatan Republik Indonesia. Info Emerging Kementerian Kesehatan Indonesia. $2020 . \quad$ [online]. Retrieved from https://infeksiemerging.kemkes.go.id (Accessed April 8, 2021).

[33] Kementerian Kesehatan Republik Indonesia. Pedoman Pencegahan dan Pengendalian Coronavirus Disease. 2020. [online]. Retrieved from Kementerian Kesehatan Republik Indonesia (Accessed April 10, 2021). 
[34] A. Silalahi. Perubahan pola hidup pada situasi covid-19 adaptasi pada pola hidup normal baru. Researchgate. Net. 2020.

[35] Kompas. (2020, October 13). Wapres Pertumbuhan Ekonomi Pada Masa Pandemi Covid-19 [online]. Retrieved from https://nasional.kompas.com/read/2020/10/13/16590021/wapr es-pertumbuhan-ekonomi-pada-masa-pandemi-covid-19masih-sulit?page=all_Accessed April 11, 2021).

[36] Tirto. (2020, August 5). Bagaimana Pandemi Covid-19 Menganggu Pola Inflasi Indonesia. [online]. Retrieved from https://tirto.id/bagaimana- pandemi-covid19 mengganggu-pola-inflasi-indonesia-2020-fVqL__ (Accessed April 10, 2021).

[37] Kompas. (2021, January 21). Ekonomi Indonesia Pada Masa Pandemi Covid-19 [online]. Retrieved from https://kompaspedia.kompas.id/baca/paparan-topik/ekonomiindonesia-pada-masa-pandemi-covid-19-potret-dan-strategipemulihan-2020-2021_Accessed April 10, 2021).

[38] Nasional Kontan. (2020, September 29). Akibat Pandemi Covid-19 Pengangguran dan Kemiskinan Diprediksi Mengalami Lonjakan[online]. Retrieved from https://nasional.kontan.co.id/news/akibat-pandemi-covid-19pengangguran-dan-kemiskinan-diprediksi-mengalamilonjakan (Accessed April 10, 2021).

[39] Liputan 6. (2020, November 24). Menaker Jumlah Pengangguran Naik Jadi 9,7 Juta Orang Akibat Pandemi Covid-19 [online]. $\quad$ Retrieved from https://www.liputan6.com/bisnis/read/4416534/menaker- jumlah-pengangguran-naik-jadi-9,7-juta-orang-akibatpandemi-covid-19_Accessed April 11, 2021).

[40] Media Indonesia (2020, May7). Pandemi Covid-19 Berpeluang Ciptakan Krisis Politik. [online]. Retrieved from https://mediaindonesia.com/politik-dan-

hukum/311139/pandemi-covid-19-berpeluang-ciptakankrisis-politik_Accessed April 11, 2021).

[41] CNN. (2020, August 19). MUI Wabah Covid Bisa Mendorong

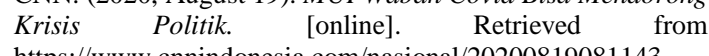
https://www.cnnindonesia.com/nasional/2020081908114332-537150/mui-wabah-covid-bisa-mendorong-krisis-politik. (Accessed April 10, 2021).

[42] Media Indonesia. (2021, January 4). Optimisme Publik Menatap Indonesia. 2021. [online]. Retrieved from https://mediaindonesia.com/kolom-pakar/373711/optimismepublik-menatap-indonesia-2021 (Accessed April 11, 2021).

[43] Tempo. (2020, September 20). Sri Mulyani Perlu Kerjasama Antar Negara. [online]. Retrieved from https://bisnis.tempo.co/read/1388278/hadapi-covid-19-srimulyani-perlu-kerja-sama-antar-negara/full\&view=ok (Accessed April 11, 2021).

[44] The Conversation. (2020, Oktober 6). Larangan 59 Negara terhadap WNI [online]. Retrieved from https://theconversation.com/larangan-terbang-59-negaraterhadap-wni-dampaknya-pada-perdagangan-indonesia-danalternatif-penanganannya-147445 (Accessed February 12, 2021). 